\title{
Vaccination of ferrets with a recombinant $G$ glycoprotein subunit vaccine provides protection against Nipah virus disease for over 12 months
}

\author{
Jackie A Pallister ${ }^{1,2^{*}}$, Reuben Klein ${ }^{1,2}$, Rachel Arkinstall ${ }^{1,2}$, Jessica Haining ${ }^{1,2}$, Fenella Long ${ }^{1,2}$, John R White ${ }^{1,2}$, \\ Jean Payne ${ }^{1,2}$, Yan-Ru Feng ${ }^{3}$, Lin-Fa Wang ${ }^{1,2,4}$, Christopher C Broder ${ }^{3}$ and Deborah Middleton ${ }^{1,2}$
}

\begin{abstract}
Background: Nipah virus (NiV) is a zoonotic virus belonging to the henipavirus genus in the family Paramyxoviridae. Since NiV was first identified in 1999, outbreaks have continued to occur in humans in Bangladesh and India on an almost annual basis with case fatality rates reported between $40 \%$ and $100 \%$.

Methods: Ferrets were vaccinated with 4, 20 or $100 \mu \mathrm{g} \mathrm{HeVsG}$ formulated with the human use approved adjuvant, $\mathrm{CpG}$, in a prime-boost regime. One half of the ferrets were exposed to NiV at 20 days post boost vaccination and the other at 434 days post vaccination. The presence of virus or viral genome was assessed in ferret fluids and tissues using real-time PCR, virus isolation, histopathology, and immunohistochemistry; serology was also carried out. Non-immunised ferrets were also exposed to virus to confirm the pathogenicity of the inoculum.

Results: Ferrets exposed to Nipah virus 20 days post vaccination remained clinically healthy. Virus or viral genome was not detected in any tissues or fluids of the vaccinated ferrets; lesions and antigen were not identified on immunohistological examination of tissues; and there was no increase in antibody titre during the observation period, consistent with failure of virus replication. Of the ferrets challenged 434 days post vaccination, all five remained well throughout the study period; viral genome - but not virus - was recovered from nasal secretions of one ferret given $20 \mu \mathrm{g} \mathrm{HeVsG}$ and bronchial lymph nodes of the other. There was no increase in antibody titre during the observation period, consistent with lack of stimulation of a humoral memory response.

Conclusions: We have previously shown that ferrets vaccinated with 4, 20 or $100 \mu \mathrm{g} \mathrm{HeVsG}$ formulated with CpG adjuvant, which is currently in several human clinical trials, were protected from HeV disease. Here we show, under similar conditions of use, that the vaccine also provides protection against NiV-induced disease. Such protection persists for at least 12 months post-vaccination, with data supporting only localised and self-limiting virus replication in 2 of 5 animals. These results augur well for acceptability of the vaccine to industry.
\end{abstract}

Keywords: Nipah virus, Hendra virus, Henipavirus, Paramyxovirus, Ferret, Immunity, Vaccination, Glycoprotein, Subunit vaccine, Longevity

\footnotetext{
* Correspondence: jackie.pallister@csiro.au

${ }^{1}$ CSIRO Livestock Industries, Australian Animal Health Laboratory, 5

Portarlington Road, Geelong, VIC 3220, Australia

${ }^{2}$ CSIRO Biosecurity Flagship, Australian Animal Health Laboratories, 5

Portarlington Road, Geelong, VIC 3220, Australia

Full list of author information is available at the end of the article
} 


\section{Background}

Nipah virus $(\mathrm{NiV})$ is a zoonotic virus belonging to the henipavirus genus in the family Paramyxoviridae. Hendra virus $(\mathrm{HeV})$ is the only other recognised member of the henipavirus genus [1], although there is increasing evidence of a range of henipa-like and other paramyxoviruses [2-6], particularly in bats which are the reservoir host for both $\mathrm{NiV}$ and $\mathrm{HeV}$. $\mathrm{HeV}$ and $\mathrm{NiV}$ are classified as BioSafety Level 4 (BSL-4) agents, a designation that reflects their ability to cause significant morbidity and mortality in humans as well as the absence of vaccines and post-exposure treatments. Since NiV was first identified [7] outbreaks have occurred in humans on an almost annual basis with case fatality rates generally reported between $40 \%$ and $100 \%$ [8]. Human-to-human transmission, although not yet observed for $\mathrm{HeV}[9,10]$, has been recorded in $\mathrm{NiV}$ outbreaks in Bangladesh. Here the local custom of family nursing infected members has resulted in extended exposure to infectious bodily secretions, particularly respiratory fluids [11]. Documentation of human-to-human transmission in this highly virulent group of viruses confirms the possibility of sustained endemic human-to-human transmission and the attendant consequences.

Vaccination is an important component of outbreak preparedness and considerable data has now been accumulated on a subunit vaccine incorporating the $G$ glycoprotein of $\mathrm{HeV}(\mathrm{HeVsG})$. The $\mathrm{HeVsG}$ vaccine has so far proved effective in preventing disease following exposure to both $\mathrm{HeV}$ and $\mathrm{NiV}$. This is as predicted because the $\mathrm{G}$ glycoproteins of $\mathrm{NiV}$ and $\mathrm{HeV}$ share 83\% amino acid identity [12] and also host cell receptors - ephrin B2 and ephrin B3 [13-15]. Cats vaccinated with $\mathrm{HeVsG}$ produced high levels of neutralising antibody to both $\mathrm{HeV}$ and $\mathrm{NiV}$ [16]; neutralising antibody to surface glycoprotein has been shown to be particularly effective in protecting against infection with viruses like the henipaviruses that have a viraemic phase [17-19]. Most vaccinated animals not only remained clinically well following exposure to virus but had no evidence of infection, including no boost in vaccinal antibody titres. Vaccination with $\mathrm{HeVsG}$ has also been shown to prevent $\mathrm{NiV}$ infection in cats and nonhuman primates, and $\mathrm{HeV}$ infection in ferrets [16,20-22] and horses. In this last case, HeVsG antigen forms the basis of a commercially available vaccine for $\mathrm{HeV}$ - the first vaccine licensed and deployed for use against a BSL-4 agent (Middleton et al., manuscript in preparation). Here we show that ferrets vaccinated with $\mathrm{HeVsG}$ were equally protected against $\mathrm{NiV}$ disease at 20 days post vaccination as against $\mathrm{HeV}$ [22]. Furthermore, protection from disease persisted for over 12 months.

\section{Results}

Nipah virus challenge of immunized ferrets

The aim of this study was to determine whether a HeVsG based vaccine protected ferrets against disease caused by $\mathrm{NiV}$ and the duration of any vaccine-induced protection. Eight ferrets were exposed to an otherwise lethal dose of $\mathrm{NiV}$ at either 20 days post vaccination (study 1) or 14 months post vaccination (study 2).

Study 1: Two control ferrets $1-0$ and 2-0 were given only adjuvant; $1-0$ was febrile on day 5 pi and was euthanized on day 6 pi, while 2-0 was febrile on days 7 and 8 pi and was euthanized on day $10 \mathrm{pi}$. Two vaccinated ferrets, 4-4 and 7-100 were euthanized prior to exposure to virus for reasons unassociated with the scientific study. The remaining vaccinated ferrets, 3-4, 5-20, 6-20 and 8-100 remained clinically healthy and were electively euthanized on day 41 of the study.

Study 2: Two control ferrets, $9-0$ and $10-0$ became febrile and exhibited reduced playfulness by day $8 \mathrm{pi}$; both were euthanized. Ferret $15-100$ was euthanized prior to exposure to virus for reasons unassociated with the scientific study. The remaining vaccinated ferrets, 11-4, $12-4,13-20,14-20$ and 16-100 remained clinically healthy and were electively euthanized on day 455 (21 days pi) of the study.

\section{Gross pathology, histopathology and immunohistochemistry}

Study 1. Control ferrets $1-0$ and 2-0 both had histological lesions including widespread deposition of $\mathrm{NiV}$ antigen consistent with acute $\mathrm{NiV}$ infection as previously described [23]. No significant histological lesions were detected in the remaining 4 ferrets, 3-4, 5-20, 6-20 and 8-100 and NiV antigen was not detected in any of their tissues.

Study 2. Control ferrets $9-0$ and $10-0$ both had histological lesions including widespread deposition of $\mathrm{NiV}$ antigen consistent with acute $\mathrm{NiV}$ infection as previously described [23]. No significant histological lesions were detected in the tissues of vaccinated ferrets, $11-4,12-4$, $13-20,14-20$, and $16-100$ and NiV antigen was not detected in any of their tissues.

\section{Viral RNA detection and virus isolation}

Viral RNA detection results for study 1 are shown in Table 1. Viral RNA was found in all fluids, swabs and tissues of control ferrets $1-0$ and $2-0$ and virus was reisolated from tissues collected from them post mortem. $\mathrm{C}_{\mathrm{t}}$ results for positive samples and tissues are shown in Table 2. Where virus was isolated from viral RNA positive samples the titre was generally not greater than $10^{5}$ $\mathrm{TCID}_{50} / \mathrm{ml}$. These data confirm that virus exposure was sufficient to induce serious infection in the naïve animal. In contrast viral RNA was not detected in any swabs, 
Table 1 Study 1: Genome detection in ferrets challenged at day 20 post vaccination

\begin{tabular}{|c|c|c|c|c|c|c|c|c|c|}
\hline \multirow{2}{*}{$\begin{array}{l}\text { Ferret\# - dose } \\
\text { HeVsG }\end{array}$} & \multirow{2}{*}{$\begin{array}{l}\text { Ab titre to NiV } \\
\text { at challenge }\end{array}$} & \multirow{2}{*}{$\begin{array}{l}\text { Eut } \\
\text { dpc }\end{array}$} & \multicolumn{6}{|c|}{ Genome detected by PCR (dpc) } & \multirow{2}{*}{$\begin{array}{l}\text { Virus positive } \\
\text { tissues }\end{array}$} \\
\hline & & & $\begin{array}{l}\text { Oral } \\
\text { swab }\end{array}$ & $\begin{array}{l}\text { Rectal } \\
\text { swab }\end{array}$ & Blood & $\begin{array}{l}\text { Nasal } \\
\text { wash }\end{array}$ & Urine & Tissues & \\
\hline $1-0$ & $<2$ & 6 & PM & PM & PM & PM & PM & $13 / 13$ & $8 / 13$ \\
\hline $2-0$ & $<2$ & 10 & $6,8, \mathrm{PM}$ & 8, PM & 8, PM & 8, PM & PM & $13 / 13$ & $6 / 13$ \\
\hline $3-4$ & 64,64 & 21 & - & - & - & - & - & $0 / 13$ & ND \\
\hline $4-4$ & NC & na & NC & NC & NC & NC & NC & NC & ND \\
\hline $5-20$ & 256,256 & 21 & - & - & - & - & - & $0 / 13$ & ND \\
\hline $6-20$ & 256,512 & 21 & - & - & - & - & - & $0 / 13$ & ND \\
\hline $7-100$ & NC & na & NC & NC & NC & NC & NC & NC & ND \\
\hline $8-100$ & 256,512 & 21 & - & - & - & - & - & $0 / 13$ & ND \\
\hline
\end{tabular}

$A b$ antibody, Eut $d p c$ day post challenge that ferrets were euthanized PM post mortem, NC no challenge, ND not done; -, no viral RNA detected, na not applicable.

fluids or tissues collected from the 4 vaccinated ferrets either during the immediate post-exposure period or at post mortem examination; this included ferret 3-4 which had received the lowest dose $(4 \mu \mathrm{g})$ of $\mathrm{HeVsG}$.

Viral RNA detection results for study 2 are shown in Table 3; the pattern of genome detection and virus reisolation from the control ferrets $9-0$ and $10-0$ confirmed an otherwise lethal exposure to NiV. Viral genome was not detected in any swabs, fluids or tissues from 3 of the 5 vaccinated ferrets. In one animal (ferret 14-20), viral genome was detected in nasal washes at day 6 and day $8 \mathrm{pi}$ and, in another (ferret 13-20), from the bronchial lymph nodes at post mortem. In neither case was virus reisolated from these samples. $C_{t}$ results for positive samples and tissues are shown in Table 2. Where virus was isolated from viral RNA positive samples the titre was generally not greater than $10^{5} \mathrm{TCID}_{50} / \mathrm{ml}$

\section{Post-challenge serology}

In both studies sera were collected at the time of exposure to virus; day 6,8 and $10 \mathrm{pi}$, and at euthanasia. There was no clear cut evidence of an anamnestic antibody response in either group.

\section{Conclusions}

As the human population expands into previously untouched environments there are increasing reports of viruses that have co-existed for long periods of time in their reservoir hosts 'spilling over' to emerge as novel human infections. The recent example of such an agent, human immunodeficiency virus (HIV), demonstrates the devastating economic and social impact that these events may have on human populations. Although the virus was not identified until 1981, HIV is thought to have made the initial jump from chimpanzees into

Table $\mathbf{2} C_{t}$ values in genome positive samples in studies $\mathbf{1}$ and $\mathbf{2}$

\begin{tabular}{|c|c|c|c|c|c|c|c|}
\hline \multirow[t]{2}{*}{ Sample } & \multirow[t]{2}{*}{ Sample day } & \multicolumn{6}{|c|}{ Genome detected by PCR $\left(C_{t}\right)$} \\
\hline & & $1-0$ & $2-0$ & $9-0$ & $10-0$ & $13-20$ & $14-20$ \\
\hline \multirow[t]{3}{*}{ Oral swab } & D6 & - & 31.4 & - & 32.6 & - & - \\
\hline & D8 & - & 34.8 & - & - & - & - \\
\hline & PM & 33.6 & 30.5 & 38.0 & 31.9 & - & - \\
\hline \multirow[t]{3}{*}{ Rectal swab } & D6 & - & - & - & 35.8 & - & - \\
\hline & D8 & - & 37.5 & - & - & - & - \\
\hline & PM & 33.3 & 31.2 & - & 35.4 & - & - \\
\hline \multirow[t]{3}{*}{ Blood } & D6 & - & - & - & 36.6 & - & - \\
\hline & D8 & - & 32.9 & 38.3 & - & - & - \\
\hline & PM & 30.2 & 30.1 & - & 26.5 & - & - \\
\hline \multirow[t]{3}{*}{ Nasal wash } & D6 & - & - & - & 29.4 & - & 34.1 \\
\hline & D8 & - & 36.4 & - & - & - & 32.3 \\
\hline & PM & 28.0 & 29.6 & 31.9 & 31.9 & - & - \\
\hline Urine & PM & 31.0 & 29.1 & 34.7 & 31.9 & - & - \\
\hline Tissues & PM & ${ }^{1} 18-34.7$ & $18.0-30.9$ & $18.6-36.6$ & $16.4-37.8$ & $\mathbf{2}_{33.8}$ & - \\
\hline
\end{tabular}

$1-0,2-0=$ control ferrets, study $1 ; 9-0,10-0=$ control ferrets, study $2 ; 13-20,13-20=$ ferrets receiving $20 \mu g$ HeVsG in study 2 . PM post mortem; -, no viral RNA detected. ${ }^{1}$ Range of $C_{t}$ values in tissues; ${ }^{2}$ bronchial lymph nodes. 
Table 3 Study 2: Genome detection in ferrets challenged at 434 days post vaccination

\begin{tabular}{|c|c|c|c|c|c|c|c|c|c|}
\hline \multirow{2}{*}{$\begin{array}{l}\text { Ferret \# - dose } \\
\text { HeVsG }\end{array}$} & \multirow{2}{*}{$\begin{array}{l}\text { Ab titre to NiV } \\
\text { at challenge }\end{array}$} & \multirow{2}{*}{$\begin{array}{l}\text { Eut } \\
\text { dpc }\end{array}$} & \multicolumn{6}{|c|}{ Genome detected by PCR (dpc) } & \multirow{2}{*}{$\begin{array}{l}\text { Virus positive } \\
\text { tissues }\end{array}$} \\
\hline & & & Oral swab & $\begin{array}{l}\text { Rectal } \\
\text { swab }\end{array}$ & Blood & $\begin{array}{l}\text { Nasal } \\
\text { wash }\end{array}$ & Urine & Tissues & \\
\hline $9-0$ & $<4,<4$ & 8 & PM & - & PM & PM & PM & $13 / 13$ & $10 / 13$ \\
\hline $10-0$ & $<4,<4$ & 8 & $6, \mathrm{PM}$ & $6, \mathrm{PM}$ & 6, PM & 6, PM & PM & $13 / 13$ & $10 / 13$ \\
\hline $11-4$ & 32,128 & 20 & - & - & - & - & - & - & ND \\
\hline $12-4$ & 32,64 & 20 & - & - & - & - & - & - & ND \\
\hline $13-20$ & 16,16 & 20 & - & - & - & - & - & $1 / 13$ & $0 / 13$ \\
\hline $14-20$ & 64,128 & 20 & - & - & - & 6,8 & - & & - \\
\hline $15-100$ & $N C$ & na & $N C$ & NC & $\mathrm{NC}$ & NC & NC & $N C$ & NC \\
\hline $16-100$ & 64,64 & 20 & - & - & - & - & - & - & ND \\
\hline
\end{tabular}

$A b$ antibody, Eut dpc day post challenge that ferrets were euthanized, PM post mortem, ND not done, NC no challenge; -, no viral RNA detected, na not applicable.

humans at the beginning of the $20^{\text {th }}$ century. By 2010 , 34 million people were living with acquired immunodeficiency syndrome (AIDS) and in the same year 2.4-2.9 million people were newly infected with $\mathrm{HIV}$. $\mathrm{HeV}$ and $\mathrm{NiV}$ were also discovered relatively recently $-\mathrm{HeV}$ was isolated and identified in 1994 when it caused the death of 20 horses and 1 human [24] and NiV in 1998-9 after an outbreak in pigs and humans in Peninsular Malaysia and Singapore [7]. They were identified as paramyxoviruses but were sufficiently distinct to be assigned to a new genus, Henipavirus, within the Paramyxoviridae $[25,26]$. Their large genome was atypical as was their pathogenicity for a range of species, with reported mortality rates in humans of up to $100 \%$ for $\mathrm{NiV}$ and $57 \%$ for $\mathrm{HeV}$. All human cases of $\mathrm{HeV}$ infection to date have resulted from close contact with secretions of infected horses either late in incubation period, during terminal illness, or at post mortem examination. There is no known instance of transmission directly to humans from the reservoir host, the bat, or of human-to-human transmission of $\mathrm{HeV}$. In contrast, $\mathrm{NiV}$ in Bangladesh can be transmitted directly from bats to people and this has been linked epidemiologically to the consumption of contaminated palm sap; human-to-human transmission also occurs here and is thought to be facilitated by families nursing sick relatives with attendant copious exposure to infected bodily fluids [27]. Repeated spillover events into human (and other animal populations) have been documented for both $\mathrm{HeV}$ and $\mathrm{NiV}$ [8] suggesting persistence of the environmental circumstances that facilitated the initial emergence event. Spillover is thus likely to be ongoing, and it is conceivable that a future incident with increasing host adaptation might result in establishment of $\mathrm{HeV}$ or $\mathrm{NiV}$ in human populations, with an impact exacerbated by high mortality rates and no pre-existing immunity.

The sporadic occurrence of viral spillover events creates major challenges for emergency disease preparedness activities. However, in the $15-20$ years since $\mathrm{HeV}$ and $\mathrm{NiV}$ were first identified substantial progress has been made in the development of vaccines and therapeutics for the prevention and treatment of infection with these viruses. The HeVsG vaccine, which prevents $\mathrm{HeV}$ disease in horses, is the first to be registered for use against a BSL-4 agent, and a therapeutic monoclonal antibody is currently being assessed for human use [23,28]. While the focus in Australia is on management of the infection risks posed by $\mathrm{HeV}$ infection, studies have shown that the $\mathrm{HeVsG}$ vaccine provides equally powerful cross-protection against $\mathrm{NiV}$ infection in cats and nonhuman primates.

Our current studies indicate that at the time of onset of protection the $\mathrm{HeVsG}$ vaccine can reliably protect ferrets from acute NiV disease and also prevent infection providing so-called sterilizing immunity - consistent with earlier studies using $\mathrm{HeV}$ [22]. Here we have also shown, in the first duration of protection study in an animal model, protection from disease persists at least 14 months after vaccination in ferrets. Recovery of viral genome (but not live virus) from the nasal washes of one animal and from the bronchial lymph nodes of another, in the absence of a rise in antibody titre, are consistent with self-limiting local virus replication at a level insufficient to generate an anamnestic immune response or to sustain a transmission event.

The animal numbers reported here are necessarily small due partly to the limitations of the BSL4 facility but also because 3 ferrets were euthanized before challenge leaving 3 groups in the 2 studies with a group size of 1 . While no conclusion can be drawn from a group size of 1 there were 3 remaining groups where $n=2$, the $20 \mu \mathrm{g}$ group in both studies and the $4 \mu \mathrm{g}$ group in study 2. Data from these groups indicated that the vaccine induced protection sufficient to suppress the course of a human pandemic persists for at least 12 months. The data from the reduced groups also support this conclusion. 
Importantly, in the event of a spillover leading to sustained human-to-human transmission of $\mathrm{HeV}$ or $\mathrm{NiV}$, proof of concept studies already exist for the sG subunit vaccine in two animal models of which one is a nonhuman primate. This is relevant to the US FDA animal rule that states where a medical countermeasure cannot be evaluated in humans, in vivo evaluation of a vaccine or therapeutic may be translated from the outcomes of work in two animal models. Finally, the experimental vaccine given to ferrets uses a formulation that is in clinical trials in humans.

Recrudescence in the form of encephalitis has been documented for both $\mathrm{HeV}$ and $\mathrm{NiV}$ and is thought to be due to persistence of the virus in some form within the central nervous system. A farmer from Mackay, Australia developed encephalitis 13 months after apparent recovery from acute meningencephalitis caused by $\mathrm{HeV}$ and died with evidence of $\mathrm{HeV}$ in the brain as detected by PCR, electron microscopy and immunohistochemistry [29]. In the initial $\mathrm{NiV}$ outbreak in Malaysia $7.5 \%$ of survivors went on to develop relapsing encephalitis and $3.4 \%$ suffered late-onset encephalitis months to years after recovery from the initial infection [30,31]. Recent studies have shown that $\mathrm{HeV}$ can infect the mouse brain via an anterograde route of infection, probably along the olfactory nerve [32] as also suggested for NiV in pigs [33]. This suggests that an effective henipavirus vaccine will need to suppress the initial phase of replication in the upper respiratory tract (summarized in [8]) to a level that prevents infection of olfactory sensory neurons as well as preventing the onset of viremia.

The HeVsG subunit vaccine has proved highly effective in suppression of virus replication and disease prevention, with duration of protection that is sufficient to make the formulation attractive to industry. A vaccine incorporating the $\mathrm{HeVsG}$ antigen has now been released for use in horses and its application and observed effectiveness, along with ongoing work in animal models including nonhuman primates, will enable a more rapid response to any future henipavirus spillover events that threaten to cause large scale outbreaks in humans.

\section{Methods}

\section{Animals, accommodation, handling and biosafety}

Eight male ferrets aged $12-18$ months were used in each of 2 experiments. Those exposed to $\mathrm{NiV}$ at 20 days post vaccination (study 1 ) were housed in pairs in cages in a single room at PC-3 or 4 for the duration of the study. Those exposed to NiV at 413 days post vaccination (study 2) were housed in pairs in cages at PC2 until the time of virus exposure, when they were moved to a single room at BSL-4. Animal husbandry was carried out as described in [22], and animal husbandry methods and experimental design were endorsed by the
Australian Animal Health Laboratory's Animal Ethics Committee.

\section{Animal infection}

All ferrets were exposed to $5000 \mathrm{TCID}_{50}$ of a low passage isolate of NiV-Bangladesh/human/2004/Rajbari, R1 [34,35]. This represents 10 times the minimum infectious dose determined for this virus in ferrets. General clinical observations were documented daily before and after infection (pi). Animals were weighed while under sedation at the time of vaccinations, virus exposure, and at days $6,8,10$ and 21 pi. Rectal temperature was also recorded at sedation to augment data derived remotely from the implanted temperature transponders. Ferrets were euthanized when reaching a previously determined endpoint or at 21 days pi. The humane endpoint was defined as rapidly progressive clinical illness of up to 2 days duration including fever and depression, possibly accompanied by increased respiratory rate or posterior paresis or ataxia. In susceptible animals, this typically occurs within the first 10 days after viral challenge. In preliminary studies, these signs were found to correlate with the requirement to euthanize ferrets on subsequent days on humane grounds; thus, they have been utilized as surrogates for lethality.

\section{Vaccine immunogen preparation}

A human codon optimized $\mathrm{HeV}$ soluble glycoprotein $\mathrm{G}$ (sG) construct was used to produce recombinant $\mathrm{HeVsG}$ as described [22]. CpG oligodeoxynucleotide (ODN) 2007 (TCGTCGTTGTCGTTTTGTCGTT) containing a fully phosphorothioate backbone was purchased from Invivogen (San Diego, CA, USA) and Alhydrogel ${ }^{\mathrm{TM}}$ was purchased from Accurate Chemical \& Scientific Corporation (Westbury, NY, USA). Vaccine doses containing fixed amount of CpG ODN 2007 and varying amounts of $\mathrm{HeVsG}$ and aluminum ion (at a weight ratio of 1:25) were formulated as follows: $4 \mu \mathrm{g} \mathrm{sGHeV}, 100 \mu \mathrm{g}$ aluminium ion and $150 \mu \mathrm{g}$ of CpG ODN 2007; $20 \mu \mathrm{g}$ dose: 20 $\mu \mathrm{g} \mathrm{sGHeV}, 500 \mu \mathrm{g}$ aluminium ion and $150 \mu \mathrm{g}$ of $\mathrm{CpG}$ ODN2007; and $100 \mu \mathrm{g}$ dose: $100 \mu \mathrm{g}$ HeVsG, $2.5 \mathrm{mg}$ aluminium ion and $150 \mu \mathrm{g}$ of CpG ODN 2007. For all doses, Alhydrogel ${ }^{\mathrm{TM}}$ and sGHeV were mixed first before CpG ODN 2007 was added. Each vaccine dose was adjusted to $1 \mathrm{ml}$ with PBS and mixtures were incubated on a rotating wheel at room temperature for at least $2-3 \mathrm{~h}$ prior to injection.

\section{Immunisation}

For both studies, ferrets were divided randomly into 4 groups of 2, with each group receiving vaccine or adjuvant alone as follows: study $1-1-0$ and 2-0 received adjuvant only, 3-4 and 4-4 were vaccinated with $4 \mu \mathrm{g}$ HeVsG, 5-20 and 6-20 with $20 \mu \mathrm{g}$ HeVsG and 7-100 
and 8-100 with $100 \mu \mathrm{g} \mathrm{HeVsG.} \mathrm{Similarly} \mathrm{for} \mathrm{study} \mathrm{2,} \mathrm{fer-}$ rets numbered $9-0$ and $10-0,11-4$ and $12-4,13-20$ and 14-20, 15-100 and 16-100 received $0,4,20$ and $100 \mu \mathrm{g} \mathrm{HeVsG}$ respectively. The vaccine was administered subcutaneously with a priming dose at day 0 and a booster dose 20 days later.

\section{Sample collection}

Nasal washes, oral and rectal swabs and blood samples both in EDTA and for serum preparation, were taken at the time of vaccination and virus exposure, then at days $6,8,10$ and 21 pi as described in [22]. Urine was collected only at post mortem examination when tissues were also collected for virus isolation, viral genome detection, histology, and immunohistology as described in [22]. These tissues included adrenal gland, bladder, brain, olfactory pole, heart, kidney, liver, apical lung lobe, diaphragmatic lung lobe, bronchial lymph node, retropharyngeal lymph node, spleen and testes.

\section{Sample analysis}

TaqMan PCR assay for the detection of the NiV N gene, immunohistochemical evaluation using a rabbit polyclonal antibody raised against the $\mathrm{NiV} \mathrm{N}$ protein [36], histology, serum neutralization titres against $\mathrm{NiV}$ and virus isolation were carried out according to [22].

\section{Competing interests}

CCB is a United States federal employee and an inventor on pending United States patents and Australian patent 2005327194, pertaining to soluble forms of Hendra and Nipah G glycoproteins; assignees are The United States of America as represented by the Department of Health and Human Services (Washington, DC), Henry M. Jackson Foundation for the Advancement of Military Medicine, Inc. (Bethesda, MD).

\section{Authors' contributions \\ JAP designed the study, processed animal tissues, carried out virus isolation and serology and drafted the manuscript. RK processed animal tissues, carried out real-time PCR, virus isolation and serology. RA and $J \mathrm{H}$ carried out the animal infection studies. FL read histopathology and \\ immunohistopathology slides. JRW extracted viral RNA from animal tissues and fluids. JP processed tissues for histopathology and \\ immunohistopathology. LFW conceived the study and edited the manuscript. CCB conceived the study, provided funds and edited the manuscript. DM conceived and designed the study, supervised animal infection studies, provided veterinary pathology expertise and edited the manuscript. All authors read and approved the final manuscript.}

\section{Acknowledgements}

The authors would like to thank Chris Cowled and Glenn Marsh for critical review of this manuscript. Also Jenni Rookes for preparation of slides for histology and immunohistochemistry, Tyrone McDonald for extraction of viral RNA, and Leah Frazer for ferret husbandry and monitoring ferrets at BSL-4. This work was supported by NIH grant 1 U01 Al077995-01.

\section{Author details}

${ }^{1}$ CSIRO Livestock Industries, Australian Animal Health Laboratory, 5 Portarlington Road, Geelong, VIC 3220, Australia. ${ }^{2}$ CSIRO Biosecurity Flagship, Australian Animal Health Laboratories, 5 Portarlington Road, Geelong, VIC 3220, Australia. ${ }^{3}$ Department of Microbiology and Immunology, Uniformed Services University, Bethesda, MD 20814, USA. ${ }^{4}$ Program in Emerging Infectious Diseases, Duke-NUS Graduate Medical School, Singapore 169857, Singapore.
Received: 3 June 2013 Accepted: 11 July 2013

Published: 16 July 2013

\section{References}

1. Eaton BT, Mackenzie JS, Wang LF: Henipaviruses. In Fields Virology. Edited by Knipe DM, Griffin DE, Lamb RA, Straus SE, Howley PM, Martin MA, Roizman B. Philadelphia: Lippincott Williams \& Wilkins; 2007:1587-1600.

2. Marsh GA, De Jong C, Barr JA, Smith C, Middleton D, Yu M, Todd S, Foord A, Haring V, Payne J, et al: Cedar virus: a novel virus isolated from Australian bats. PLOS Pathog 2012, 8:1-11.

3. Li Y, Wang J, Hickey AC, Zhang Y, Wu Y, Zhang H, Yuan J, Han Z, McEachern J, Broder CC, et al: Antibodies to Nipah or Nipah-like viruses in bats, China. Emerg Infect Dis 2008, 14:1974-1976.

4. Drexler JF, Corman VM, Gloza-Rausch F, Seebens A, Annan A, Ipsen A, Kruppa T, Muller MA, Kalko EK, Adu-Sarkodie Y, et al: Henipavirus RNA in African bats. PLoS One 2009, 4:e6367.

5. Baker KS, Todd S, Marsh G, Fernandez-Loras A, Suu-Ire R, Wood JL, Wang LF, Murcia PR, Cunningham AA: Co-circulation of diverse paramyxoviruses in an urban African fruit bat population. J Gen Virol 2012, 93:850-856.

6. Drexler JF, Corman VM, Muller MA, Maganga GD, Vallo P, Binger T, GlozaRausch F, Rasche A, Yordanov S, Seebens A, et al: Bats host major mammalian paramyxoviruses. Nat Commun 2012, 3:796.

7. Chua KB, Bellini WJ, Rota PA, Harcourt BH, Tamin A, Lam SK, Ksiazek TG, Rollin PE, Zaki SR, Shieh W, et al: Nipah virus: a recently emergent deadly paramyxovirus. Science 2000, 288:1432-1435.

8. Pallister J, Middleton D, Broder CC, Wang L-F: Henipavirus vaccine development. Journal of Bioterrorism and Biodefense 2011, S1:005.

9. Mahalingam S, Herrero LJ, Playford EG, Spann K, Herring B, Rolph MS, Middleton D, McCall B, Field H, Wang LF: Hendra virus: an emerging paramyxovirus in Australia. Lancet Infect Dis 2012, 12:799-807.

10. Selvey LA, Taylor R, Arklay A, Gerrard J: Screening of bat carers for antibodies to equine morbillivirus. Communicable Disease Intelligence 1996, 20:477-478.

11. Luby SP, Gurley ES, Hossain MJ: Transmission of human infection with Nipah virus. Clin Infect Dis 2009, 49:1743-1748.

12. Khetawat $D$, Broder CC: $A$ functional henipavirus envelope glycoprotein pseudotyped lentivirus assay system. Virol J 2010, 7:312.

13. Bonaparte MI, Dimitrov AS, Bossart KN, Crameri G, Mungall BA, Bishop KA, Choudhry V, Dimitrov DS, Wang LF, Eaton BT, Broder CC: Ephrin-B2 ligand is a functional receptor for Hendra virus and Nipah virus. Proc Natl Acad Sci USA 2005, 102:10652-10657.

14. Negrete OA, Wolf MC, Aguilar HC, Enterlein S, Wang W, Muhlberger E, Su SV, Bertolotti-Ciarlet A, Flick R, Lee B: Two key residues in ephrinB3 are critical for its use as an alternative receptor for Nipah virus. PLOS Pathog 2006, 2:e7.

15. Negrete $\mathrm{OA}$, Chu D, Aguilar HC, Lee B: Single amino acid changes in the Nipah and Hendra virus attachment glycoproteins distinguish ephrinB2 from ephrinB3 usage. J Virol 2007, 81:10804-10814.

16. Mungall BA, Middleton D, Crameri G, Bingham J, Halpin K, Russell G, Green D, McEachern J, Pritchard LI, Eaton BT, et al: Feline model of acute Nipah virus infection and protection with a soluble glycoprotein-based subunit vaccine. J Virol 2006, 80:12293-12302.

17. Graham BS, Crowe JE: Immunization against viral diseases. In Fields Virology. Edited by Knipe DM, Griffin DE, Lamb RA, Straus SE, Howley PM, Martin MA, Roizman B. Philadelphia: Lippincott Williams \& Wilkins; 2007:487-538.

18. Wolinsky JS, Waxham MN, Server AC: Protective effects of glycoproteinspecific monoclonal antibodies on the course of experimental mumps virus meningoencephalitis. J Virol 1985, 53:727-734.

19. Plotkin SA: Vaccination against the major infectious diseases. C R Acad SCi III 1999, 322:943-951.

20. McEachern JA, Bingham J, Crameri G, Green DJ, Hancock TJ, Middleton D, Feng YR, Broder CC, Wang LF, Bossart KN: A recombinant subunit vaccine formulation protects against lethal Nipah virus challenge in cats. Vaccine 2008, 26:3842-3852.

21. Bossart KN, Rockx B, Feldmann F, Brining D, Scott D, LaCasse R, Geisbert JB, Feng YR, Chan YP, Hickey AC, et al: A Hendra virus G glycoprotein subunit vaccine protects African green monkeys from Nipah virus challenge. Sci Transl Med 2012, 4:146ra107.

22. Pallister J, Middleton D, Wang LF, Klein R, Haining J, Robinson R, Yamada M, White J, Payne J, Feng YR, et al: A recombinant Hendra virus G glycoprotein-based subunit vaccine protects ferrets from lethal Hendra virus challenge. Vaccine 2011, 29:5623-5630. 
23. Bossart KN, Zhu Z, Middleton D, Klippel J, Crameri G, Bingham J, McEachern JA Green D, Hancock TJ, Chan YP, et al: A neutralizing human monoclonal antibody protects against lethal disease in a new ferret model of acute Nipah virus infection. PLoS Pathog 2009, 5:e1000642.

24. Murray K, Selleck P, Hooper P, Hyatt A, Gould A, Gleeson L, Westbury H, Hiley L, Selvey L, Rodwell B, et al: A morbillivirus that caused fatal disease in horses and humans. Science 1995, 268:94-97.

25. Wang LF, Yu M, Hansson E, Pritchard LI, Shiell B, Michalski WP, Eaton BT: The exceptionally large genome of Hendra virus: support for creation of a new genus within the family Paramyxoviridae. J Virol 2000, 74:9972-9979.

26. Mayo MA: A summary of taxonomic changes recently approved by ICTV. Arch Virol 2002, 147:1655-1663.

27. Luby SP, Gurley ES: Epidemiology of henipavirus disease in humans. Curr Top Microbiol Immunol 2012, 359:25-40.

28. Bossart KN, Geisbert TW, Feldmann H, Zhu Z, Feldmann F, Geisbert JB, Yan L, Feng YR, Brining D, Scott D, et al: A neutralizing human monoclonal antibody protects african green monkeys from hendra virus challenge. $S c i$ Transl Med 2011, 3:105ra103.

29. O'Sullivan JD, Allworth AM, Paterson DL, Snow TM, Boots R, Gleeson L, Gould AR, Hyatt AD, Bradfield J: Fatal encephalitis due to novel paramyxovirus transmitted from horses. Lancet 1997, 349:93-95.

30. Goh K, Tan CT, Chew NK, Tan PS, Kamarulzaman A, Sarji SA, Wong KT, Abdullah BJ, Chua KB, Lam SK: Clinical features of Nipah virus encephalitis among pig farmers in Malaysia. N Engl J Med 2000, 342:1229-1235.

31. Tan CT, Goh KJ, Wong KT, Sarji SA, Chua KB, Chew NK, Murugasu P, Loh YL, Chong HT, Tan KS, et al: Relapsed and late-onset Nipah encephalitis. Ann Neurol 2002, 51:703-708.

32. Dups J, Middleton D, Yamada M, Monaghan P, Long F, Robinson R, Marsh GA, Wang LF: A new model for hendra virus encephalitis in the mouse. PLoS One 2012, 7:e40308.

33. Weingartl H, Czub S, Copps J, Berhane Y, Middleton D, Marszal P, Gren J, Smith G, Ganske S, Manning L, Czub M: Invasion of the central nervous system in a porcine host by Nipah virus. J Virol 2005, 79:7528-7534.

34. Harcourt BH, Lowe L, Tamin A, Liu X, Bankamp B, Bowden N, Rollin PE, Comer JA, Ksiazek TG, Hossain MJ, et al: Genetic characterization of Nipah virus, Bangladesh, 2004. Emerg Infect Dis 2005, 11:1594-1597.

35. ICDDRB: Nipah virus encephalitis outbreak over a wide area of western Bangladesh, 2004. Health and Science Bulletin 2004, 2:7-11.

36. Middleton DJ, Westbury HA, Morrissy CJ, van der Heide BM, Russell GM, Braun MA, Hyatt AD: Experimental Nipah virus infection in pigs and cats. J Comp Pathol 2002, 126:124-136

doi:10.1186/1743-422X-10-237

Cite this article as: Pallister et al.: Vaccination of ferrets with a recombinant $\mathrm{G}$ glycoprotein subunit vaccine provides protection against Nipah virus disease for over 12 months. Virology Journal 2013 10:237.

\section{Submit your next manuscript to BioMed Central and take full advantage of:}

- Convenient online submission

- Thorough peer review

- No space constraints or color figure charges

- Immediate publication on acceptance

- Inclusion in PubMed, CAS, Scopus and Google Scholar

- Research which is freely available for redistribution 